\title{
Growth, gas exchange and yield of peanut in frequency of irrigation ${ }^{1}$
}

\author{
Crescimento, trocas gasosas e produtividade do amendoim sob frequência de \\ irrigação \\ Geocleber Gomes de Sousa ${ }^{2 *}$, Benito Moreira de Azevedo ${ }^{3}$, Carlos Newdmar Vieira Fernandes ${ }^{4}$, Thales Vinicius \\ de Araújo Viana ${ }^{3}$ e Maria Lilian Santos Silva ${ }^{3}$
}

\begin{abstract}
This study was conducted to evaluate the effect of different irrigation frequencies on growth, gas exchange and yield of the peanut (Arachis ypogea $\mathrm{L}$ ). The experiment was conducted in the field using the experimental design of randomized blocks with five treatments, five replications with four plants per plot. The treatments were composed: $\mathrm{F} 2=$ (irrigation every 2 days), F4 = (irrigation every 4 days), F6 = (irrigation every 6 days), F8 = (irrigation every 2 days) and F10 = (irrigation every 10 days). At 60 days after sowing (DAS), the gas exchange variables (photosynthesis, stomatal conductance and transpiration) and growth variables (plant height, leaf number, stem diameter and shoot dry matter) were evaluated. The highest irrigation frequency tested (every two days) promoted the best results for plant growth (leaf number, plant height, shoot dry matter) e for leaf gas exchange. The highest yield of field grown peanuts at the conditions prevailing in Fortaleza, Ceará, is associated with the adoption of an irrigation frequency interval of two days.
\end{abstract}

Key words: Arachis ypogea L.. Growth. Agricultural Irrigation.

\begin{abstract}
RESUMO - Realizou-se esse trabalho com o objetivo de avaliar o efeito de diferentes frequências de irrigação sobre o crescimento, trocas gasosas e produtividade da cultura do amendoim (Arachis ypogea L). O experimento foi desenvolvido no campo e obedeceu ao delineamento experimental de blocos ao acaso, com cinco tratamentos e cinco repetições. Os tratamentos empregados foram: F2 = (irrigado a cada dois dias), F4 = (irrigado a cada quatro dias), F6 = (irrigado a cada seis dias), F8 = (irrigado a cada dois dias) e F10 = (irrigado a cada dois dias). Aos 60 dias após a semeadura (DAS), realizaram-se medições de trocas gasosas (fotossíntese, condutância estomática e transpiração) e análise de crescimento (altura de planta, número de folhas, diâmetro do caule e matéria seca da parte aérea). Para as variáveis produtivas as plantas foram colhidas aos 90 DAS e analisadas as seguintes variáveis: número de frutos por plantas, peso de vagem, tamanho de vagem, peso de 100 sementes e produtividade. A maior frequência de irrigação testada (a cada dois dias) promoveu os melhores resultados para o crescimento de planta (número de folhas, altura da planta, matéria seca) e para trocas gasosas. A maior produtividade de amendoim cultivado em campo, nas condições de Fortaleza - Ceará está associada à adoção de uma frequência de irrigação com intervalo de dois dias.
\end{abstract}

Palavras-chave: Arachis ypogea L.. Crescimento. Irrigação Agrícola.

\footnotetext{
*Autor para correspondência

Recebido para publicação em 20/04/2012; aprovado em 16/09/2013

Parte da Tese do primeiro autor apresentada ao Programa de Pós-Graduação em Engenharia Agrí́cola da Universidade Federal do Ceará/UFC

${ }^{2}$ Departamento de Engenharia Agrícola, Centro de Ciências Agrárias, Universidade Federal do Ceará/UFC, Campus do PICI, Bloco 804, Caixa Postal 12.168, Fortaleza-CE, Brasil, 60.450-760, sousasolosgeo@ hotmail.com

33Departamento de Engenharia Agrícola, Universidade Federal do Ceará/UFC, Fortaleza-CE, Brasil, benitoazevedo@ hotmail.com; thales@ufc.br, lilian.ufc@hotmail.com

${ }^{4}$ Programa de Pós-Graduação em Engenharia Agrícola, Departamento de Engenharia Agrícola, Universidade Federal do Ceará/UFC, FortalezaCE, Brasil, newdmar@yahoo.com.br
} 


\section{INTRODUCTION}

The Peanut crop has a relevant economic importance due to its high nutritional value and oil content. Its seeds can be processed and used directly in human food, the canning industries, in bakeries and in biodiesel (TASSO JÚNIOR; MARQUES; NOGUEIRA, 2004). Its cultivation extends from the north to the south of the country due to its wide adaptability to different edaphoclimatic conditions (PEIXOTO et al., 2008).

The use of irrigated agriculture requires the knowledge of determining factors of irrigation management that directly interfere in greater or lesser consumption of water, soil humidity storage (SILVA et al., 2010), knowledge of the water requirements of the crops (CORREIA; NOGUEIRA, 2004) and physiological aspects (TAIZ; ZEIGER, 2009), which makes irrigation a practice that can not only increase productivity, but can also provide a product with better quality (PIRES et al., 2009).

The frequency of irrigation required by a crop, in a specific climate, depends on water content that can be stored in a specific soil type, after irrigation (BERNARDO; SOARES; MANTOVANI, 2009), the effective depth of the root system and the percentage of surface covered (SILVA et al., 2010).

The monitoring of the development of the crops through different frequencies of irrigation enables the optimization of water application in each phenological stage of the crop (SILVA; BELTRÃO, 2000). The reduction of the water availability in the soil represents a limiting factor to the crop growth and yield (MAROUELLI; SILVA, 2007).

The intervals of time between when the water is applied on the plants may cause physiological injury to the crops. The water stress reduces the photosynthetic rate of the plants, causing the closure of the stomata in order to reduce transpiration, thus affecting the absorption of $\mathrm{CO}_{2}$, reducing the leaf area and anticipates the senescence of the leaves (LARCHER, 2006; TAIZ; ZEIGER, 2009) The excessive application of water is one of the most limiting factors for obtaining high yields (FREITAS et al., 2011).

The objective of this study was to evaluate the initial growth, the gas exchanges and the productivity of the peanut crops with different irrigation frequencies in the edaphoclimatic conditions of Fortaleza, Ceará, Brazil.

\section{MATERIAL AND METHODS}

The study was conducted at the experimental station of Agrometeorology, Department of Agricultural Engineering, Federal University of Ceará, Pici Campus, Fortaleza, Ceará, Brazil, located at the geographic coordinates of $3^{\circ} 44^{\prime} 45^{\prime \prime} \mathrm{S}$ and $38^{\circ} 34^{\prime} 55^{\prime \prime} \mathrm{W}$ and $19.5 \mathrm{~m}$ above sea level in the period ranging from September to December (2010). The climate is classified according to Köppen method as Aw, that is, tropical wet, very hot, with most occurrence of rain in the summer and autumn seasons. The soil is classified as Alfissol (EMPRESA BRASILEIRA DE PESQUISA AGROPECUÁRIA, 2006). Before planting, soil samples were collected for physical and hydraulic analysis, which are presented in Table 1.

The mean climate values collected during the experiment were wind speed of $3.9 \mathrm{~m} \mathrm{~s}^{-1}$, temperature of $28.67{ }^{\circ} \mathrm{C}, 66 \%$ relative humidity, $12.5 \mathrm{~mm}$ of precipitation, $12345.025 \mathrm{mb}$ of barometric pressure and 1025.1 hours of sunshine.

Each experimental plot was $20 \mathrm{~m}$ long and there were five plantation rows. It was used spacing of $1 \times 0.2 \mathrm{~m}$, in total with 2000 plants and a planting density of 50,000 plants per hectare. At 6 days after sowing, there was a 100\% germination. In the rough-hewing, performed manually, the plants were uprooted close to the ground, leaving only one plant per hill. All the treatments were initiated at 21 days after sowing (DAS).

The experimental design was the randomized block with five treatments: $\mathrm{F} 2=$ (irrigated every two days), F4 = (irrigated every four days), F6 = (irrigated every six days), F8 = (irrigated every eight days) and F10 $=$ (irrigated every ten days), with four plants per plot. The frequencies of irrigation used were based on accumulated blades obtained following the Penman Monteith method, proposed by FAO 56 (ALLEN et al., 2006).

Table 1 - Physico hydraulic analysis of soil water in the experimental area before application of treatments

\begin{tabular}{lc}
\hline Humidity and Physical Characteristics & Depth $(\mathrm{m})$ \\
\cline { 2 - 2 } & 0 a 0.2 \\
\hline Thick sand $\left(\mathrm{g} \mathrm{kg}^{-1}\right)$ & 311 \\
Thin sand $\left(\mathrm{g} \mathrm{kg}^{-1}\right)$ & 528 \\
Silt $\left(\mathrm{g} \mathrm{kg}^{-1}\right)$ & 76 \\
Clay $\left(\mathrm{g} \mathrm{kg}^{-1}\right)$ & 85 \\
Textural class & Loamy sand \\
Soil bulk density $\left(\mathrm{kg} \mathrm{dm}^{-3}\right)$ & 1.54 \\
Density of particles $\left(\mathrm{kg} \mathrm{dm}^{-3}\right)$ & 2.59 \\
Field capacity $\left(\mathrm{m}^{3} \mathrm{~m}^{-3}\right)$ & 0.131 \\
Soil permanent wilting point $\left(\mathrm{m}^{3} \mathrm{~m}^{-3}\right)$ & 0.077 \\
Porosity $(\%)$ & 40 \\
Saturated water $\left(\mathrm{m}^{3} \mathrm{~m}^{-3}\right)$ & 0.054 \\
\hline
\end{tabular}


Once installed the irrigation system, it was performed the test for uniformity of the system through the Christiansen uniformity coefficient, obtaining $92 \%$. The irrigations were performed by dripping throughout the whole crop cycle, using a self-compensating dripper for each plant. The monitoring of soil moisture was conducted by tensiometers placed at $0.30 \mathrm{~m}$ depth in each treatment by plot (corresponding to an irrigation line) totaling 30 tensiometers throughout the whole experiment.

The mean values of the readings in the tensiometers were converted into the matric potential of soil water, with the values of $-20.4 \mathrm{kPa}$ for the treatment $\mathrm{F} 2,-49.2 \mathrm{kPa}$ for the treatment F4, $-69.0 \mathrm{kPa}$ for the treatment F6, $-80.2 \mathrm{kPa}$ for the treatment F8 and $-92.2 \mathrm{kPa}$ for the treatment F10. The average discharge of the emitters was $2.0 \mathrm{~L} \mathrm{~h}^{-1}$, with a pressure of $98 \mathrm{kPa}$.

The foundation fertilization was performed in open pits manually in soil previously irrigated to field capacity. The fertilization was performed with $13.33 \mathrm{~g}$ of urea, $294.11 \mathrm{~g}$ of superphosphate and $80 \mathrm{~g}$ of potassium chloride per pit, corresponding to doses of 15.0, 62.5 and $50 \mathrm{~kg} \mathrm{ha}^{-1}$ of $\mathrm{N}, \mathrm{P}_{2} \mathrm{O}_{5}$ and $\mathrm{K}_{2} \mathrm{O}$, respectively, according to recommended by Fernandes (1993). The doses of potassium chloride were split in two applications, the first application made on the sowing day and the second application was performed in the 25th DAS. As for the superphosphate, its full dose was applied at sowing.

At the 60th DAS, plants were collected to determine the initial growth characteristics: number of leaves (NL), plant height - PH (cm), stem diameter - SD (mm) and shoot dry matter - SDM (g plant $\left.{ }^{-1}\right)$. It was obtained, in the same period, the net photosynthetic rate; transpiration rate, and stomatal conductance, in fully expanded leaves, using a gas analyzer in the infrared (ADC System, Hoddesdon, UK), in open system, with airflow of $300 \mathrm{~mL} \mathrm{~min}^{-1}$. The measurements of gas exchange occurred between 10:00 and 11:00 hours, using radiation source of $1200 \mu \mathrm{mol} \mathrm{m} \mathrm{m}^{-2}$.

The harvest was performed at the 90th DAS, taking five plants at random from the center line of each treatment, in each block. The plants were separated by treatment and placed in screened greenhouse for three days, for the pods to dry, for homogenization of the moisture, then weighed the grain, which had 13\%.The agronomic variables evaluated in this study were: number of fruits per plant (NFP), pod weight - PW (g), 100 seeds weight - 100SW $(\mathrm{g})$ and grain yield $\left(\mathrm{kg} \mathrm{ha}^{-1}\right)$.

Kolmogorov-Smirnov test, with the $5 \%$ level of probability was applied to test the normality of the variables: plant height, leaf number, stem diameter, shoot dry matter, stomatal conductance, transpiration, photosynthesis, number of pods per plant, pod weight, 100 seed weight and yield. Following the data at each frequency of irrigation were submitted to analysis of variance and regression, using the computer program SAEG / UFV.

\section{RESULTS AND DISCUSSION}

According to the summary of the variance analysis presented in Table 2, the frequency of irrigation applied up until the 60 days after sowing (DAS) did not significantly influence the level of significance of $5 \%$ by the $\mathrm{F}$ test, the variables of the stem diameter (SD) and photosynthesis (E). On the other hand, there were significant effects between treatments for the variables: number of leaves (NL), plant height $(\mathrm{PH})$ and shoot dry matter (SDM), to the level of $5 \%$ of significance by the $\mathrm{F}$ test.

Table 2 - Summary of analysis of variance for number of leaves (NL), plant height (PH), stem diameter (SD), shoot dry matter (SDW), photosynthesis (E), stomatal conductance (gs) and transpiration (A) in peanut plants under different irrigation frequency

\begin{tabular}{lcccc}
\hline \multicolumn{1}{c}{ FV } & Treatments & Blocks & Residue & VC $(\%)$ \\
\hline \multicolumn{1}{c}{ GL } & 4 & 4 & 16 & \\
\hline \multicolumn{1}{c}{ Variables } & \multicolumn{2}{c}{ Mean Squares } \\
\hline Number of leaves & $4577,05^{*}$ & $1454,46^{*}$ & 323,71 & 17,41 \\
Plant height & $146,75^{*}$ & $8,18^{\mathrm{ns}}$ & 30,52 & 15,9 \\
Stem diameter & 1,64 & 0,62 & 0,79 & 14,67 \\
Shoot dry matter & $706,69^{* *}$ & $1363,83^{* *}$ & 71,39 & 12,36 \\
Stomatal conductance & $0,89^{* *}$ & $0,062^{\mathrm{ns}}$ & 0,07 & 30,81 \\
Photosynthesis & $36,57^{\mathrm{ns}}$ & $15,68^{\mathrm{ns}}$ & 12,35 & 13,52 \\
Transpiration & $20,7^{* *}$ & $2,87^{\mathrm{ns}}$ & 2,5 & 14,03 \\
\hline
\end{tabular}

$\mathrm{FV}=$ variation factor; $\mathrm{GL}=$ Degree of freedom; $\mathrm{VC}=$ variation coefficient; $* *=$ significant at $1 \%$ level by the test $\mathrm{F}, *=$ significant at $5 \%$ level by the test $\mathrm{F}$ and $\mathrm{ns}=$ Not significant 
The non significant effect of the diameter of the stem of the peanut crop in the different frequencies of irrigation can be a genetic ability of the plant experiencing soil water deficiency. Correia and Nogueira (2004) concluded that peanut plants resisted environments with water restrictions for up to 35 days. Another variable that also did not differ statistically among the studied treatments was photosynthesis. Nogueira et al. (2006) found that differences in vapor pressure between leaf and the air cause partial stomatal closure, reducing photosynthesis.

For the variable number of leaves, there is a linear behavior for different frequencies of peanut crop irrigation at 60 DAS, with the frequency of irrigation between two days showing the greatest number of leaves (145) (Figure 1). The decrease of this variable in the other treatments can be explained by a water deficit imposed on the ground, that according to Rahmianna, Taufiq and Yusnawan (2009) the lower the water content in the soil, the lower the leaf expansion and consequently photosynthesis (LARCHER, 2006).

Figure 1 - Number of leaves of peanut plants due to irrigation frequency

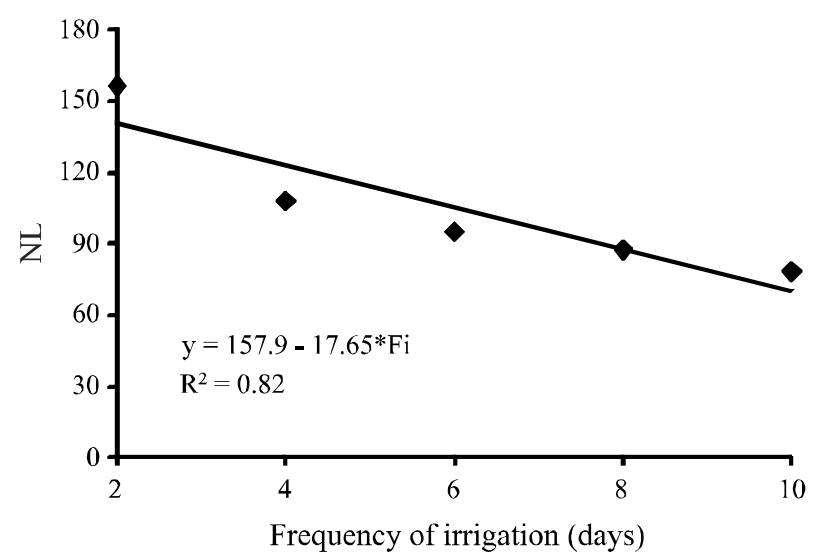

Working in greenhouse conditions, Correia and Nogueira (2004); Machado et al. (2009) researching peanuts and sugar cane under water deficit, found a decrease the number of leaves. It should be noted that water stress imposed by the reduction in the frequency of irrigation may result in a strategy in the culture by reducing the perspirant surface and the metabolic cost to tissue maintenance (INMAN-BAMBER et al., 2008), directly affecting plant growth (LARCHER, 2006).

In Figure 2, it can be observed that the reduction in frequency of irrigation significantly affected, in a linearly decreasing way, plant height at 60 DAS. Plants subjected to higher soil water deficit during the vegetative stage showed a variation in the distribution and root development and may change the period of availability and quantity of water available to plants compared to those irrigated in a scheme of higher frequency (ARAÚJO; FERREIRA , 1997), which can cause, according to Taiz and Zeiger (2009) reductions in nutrient absorbency and gas exchanges (photosynthesis, stomatal conductance and transpiration).

Figure 2 - Plant height of peanut crops due to irrigation frequency

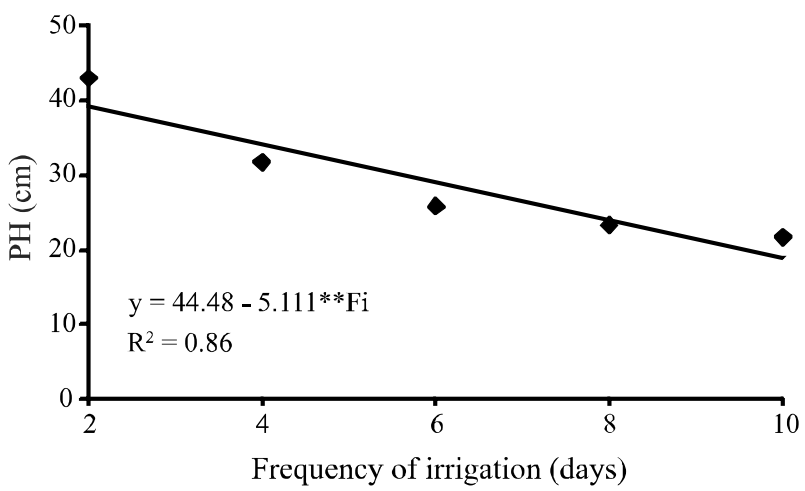

The height of tomato plants grown in a greenhouse at 43 days after transplanting; in irrigation frequency (three times daily) had the best performance (PIRES et al., 2009). Correia and Nogueira (2004) also observed reductions of grown in peanut plants height cultivated in pots under drought stress.

The shoot dry matter showed a decreasing linear model under different frequencies of irrigation at 60 DAS (Figure 3). It is pertinent to note that the more the soil dries, the more difficult is for the plants to absorb water, because the holding force increases and reduces the availability of water (NOGUEIRA et al., 2006). Silva and Beltrão (2000), studying irrigation frequencies with application every two, four, and six days, found that the best irrigation frequency for this variable, in the peanut crop, was four days. It is noted that soil texture (sandy loam) and levels $(500 \mathrm{~mm})$ by these authors were similar to this study, however the genetic factor may have contributed to this improved performance, as these authors worked with cultivar BR-1.

Confirming the results obtained in this study, Araújo and Ferreira (1997) explain that water stress leads to reduction of soil shoot dry matter of a peanut crop. Corroborating this information, Andrade and Abreu (2007) point out that the dry matter yield under drought 
is adversely affected due to reduced leaf area and consequent reduction of solar radiation intercepted and used in the production of biomass.

Figure 3 - Shoot dry matter of peanut plants due to irrigation frequency

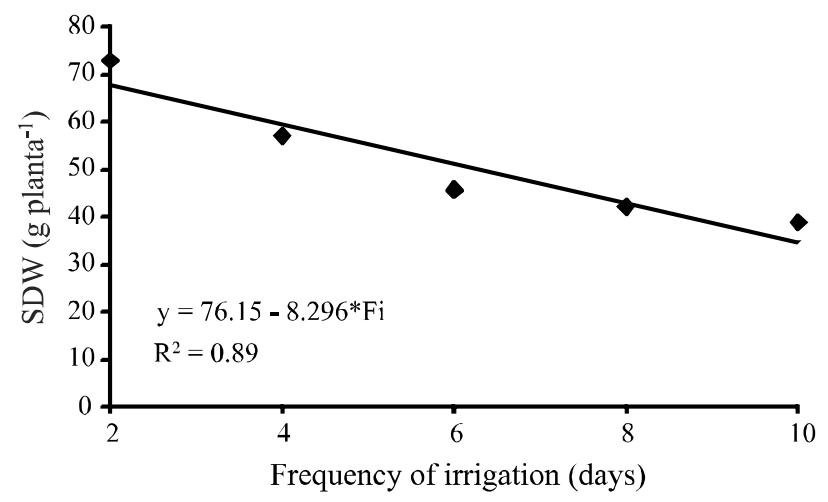

From the regression analysis, Figure 4 shows and verifies that the lower the frequency of irrigation, the lower the stomatal conductance. Taiz and Zeiger (2009) affirm that under water stress conditions, plants use as a strategy the mechanism of stomatal closure, in order to restrict water loss. On the other hand, this strategy can affect leaf gas exchange, since the stomata regulates the gas exchanges as well. Therefore changes in stomatal conductance can alter in the influx of $\mathrm{CO}_{2}$ in leaf mesophyll cells and, consequently in the rate of carbon dioxide assimilation (SHIMAZAKI et al., 2007).

The stomatal closure is a sensitive mechanism for the peanut crop, in other words, it reduces the internal water deficit, to support certain periods of drought (NOGUEIRA et al., 2006). In castor bean crop (Paraguaçu), Freitas et al. (2011) observed reductions in stomatal conductance in response to different levels $(25,50,75,100$ e $125 \%$ of the CAE) of water stress in the soil.

When analyzing the effect of different irrigation frequencies on the peanut crop transpiration through regression analysis (Figure 5), it appears that the linear model was the best fit to the data. The transpiration reduction imposed by water stress possibly reduced leaf water potential, affecting leaf area, $\mathrm{CO}_{2}$ supply for leaves and therefore photosynthesis. Evaluating physiological changes in peanut subjected to water stress, Nogueira and Santos (2000) find out that plants, after prolonged stress of 30 days, significantly reduced transpiration of control plants (no water stress) in $75 \%$.
Figure 4 - Stomatal conductance values in peanut plants under different irrigation frequency

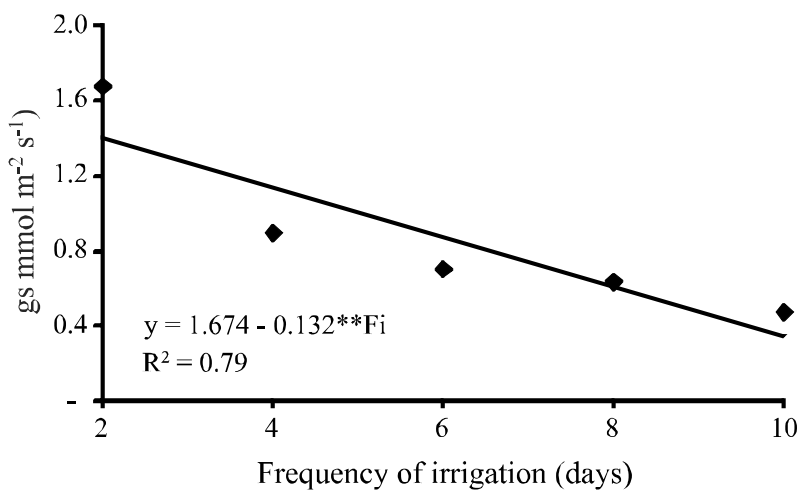

Figure 5 - Transpiration values in peanut plants under different irrigation frequency

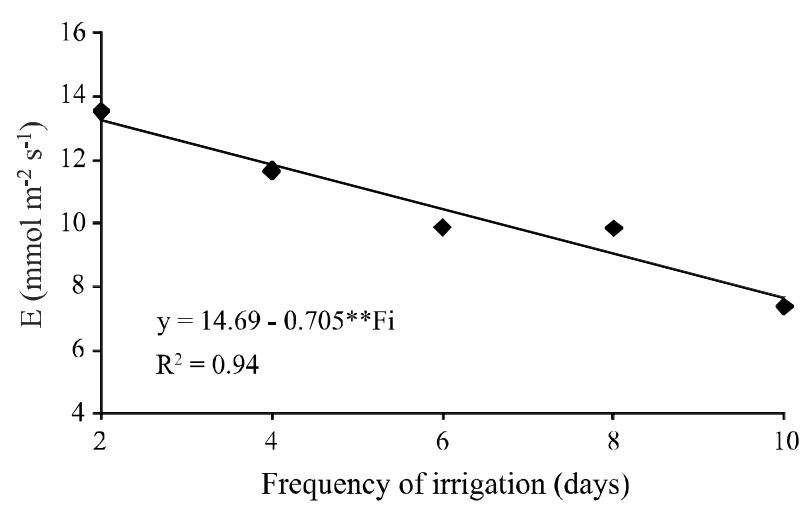

The ability to reduce perspiration allows plants to have better management of available soil water (LARCHER, 2006). Cechin et al. (2010) evaluating physiological responses in sunflower plants after six days of water stress, found that smaller stomatal lead to reduced transpiration and increased temperature of the leaf tissue. Freitas et al. (2011), analyzing the irrigation management of the castor bean under different soil water stress, found that there were no significant effects for this variable.

\section{Yield}

The different irrigation frequencies studied in this work, influenced, the number of pods per plant (NPP), the pod weight (PW), weight of 100 seeds (W100S) and the yield (Y) (Table 3).

The lowest frequency of irrigation caused significant reduction in the NPP in peanut crop (Figure 6), and in the regression analysis, the model which best fit 
Table 3 - Summary of analysis of variance for the number of fruit per plant, pod weight, 100 seeds weight and grain yield in peanut plants under different irrigation frequency

\begin{tabular}{lcccc}
\hline \multicolumn{1}{c}{ FV } & Treatments & Blocks & Residue & VC (\%) \\
\hline \multicolumn{1}{c}{ GL } & 4 & 4 & 16 & \\
\hline \multicolumn{1}{c}{ Variables } & \multicolumn{3}{c}{ Mean Squares } \\
\hline Number of fruit per plant & $991,42^{* *}$ & $19,08^{*}$ & 201,59 & 31,74 \\
Pod weight & $18968,6^{* *}$ & $623,71^{\text {ns }}$ & 2964,66 & 33,26 \\
100 seeds weight & $167,62^{* *}$ & $10,01^{\text {ns }}$ & 16,59 & 9,96 \\
Grain yield & $1251064^{* *}$ & $61865,7^{\text {ns }}$ & 107796 & 36,62 \\
\hline
\end{tabular}

$\mathrm{FV}=$ variation factor; $\mathrm{GL}=$ Degree of freedom; $\mathrm{VC}=$ variation coefficient; $* *=$ significant at $1 \%$ level by the test $\mathrm{F}, *=$ significant at $5 \%$ level by the test $\mathrm{F}$ and $\mathrm{ns}=$ Not significant

Figure 6 - Number of pods per plant in peanut crop under different irrigation frequency

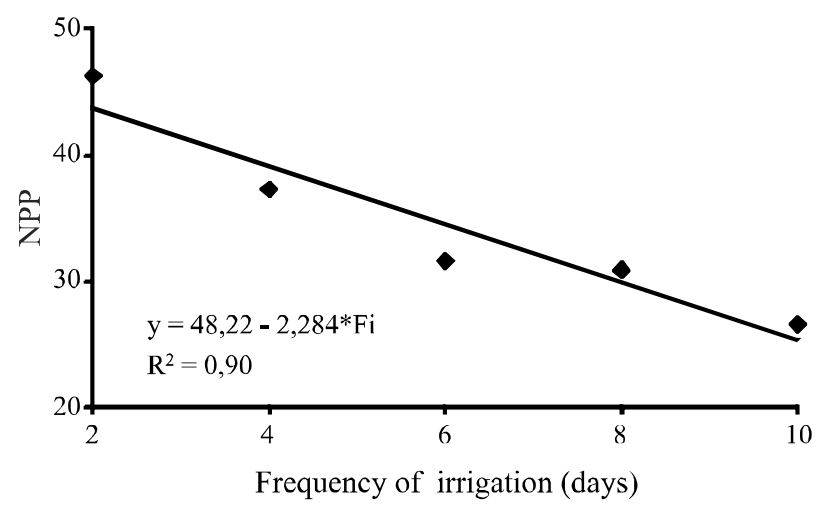

was linear. The low water availability adversely affects the growth of crops and is the main cause of reduction of productive aspects (FLEXAS et al., 2006).

The peanut crop without water stress, recorded a maximum number of pods (154) higher than this study (ARAÚJO; FERREIRA, 1997). Those researchers emphasize the treatment of non-irrigated plants from 30 to 60 days after sowing. This piece of information reveals that such plant has a certain genetic ability to withstand a period of Indian summer. Rowland et al. (2012), evaluating the number of peanut pods under different frequency of soil water stress, observed higher values than this study for the number of pods (88). Contrary to this study, Sousa and Lima (2010), found lower values for the number of pods per plant (20.87) in bean plants when analyzing different soil water stress.

For the frequencies of irrigation studied, the pod weight showed significance, at a level of $1 \%$ in the $\mathrm{F}$ test, adjusting itself also to a linear equation (Figure 7). The ten day irrigation frequency (F10) gave a reduction of $39.31 \%$ in pod weight, with respect to $\mathrm{F} 2$ peanut crop at 90 DAS. The frequency of irrigation, ten days (F10) gave a reduction in pod weight of the peanut crop at 90 DAS, i.e., the water stress in such treatment resulted in lower performance for pod weight, corroborating with data from Assunção and Escobedo (2009).

Figure 7 - Pod weight in peanut plants under different frequency irrigation

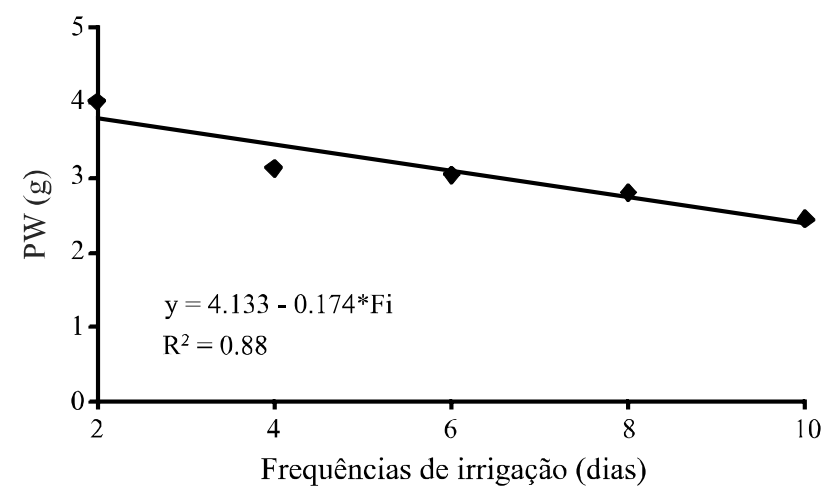

Water stress intensities caused by different cotton irrigation frequencies presented similar results for this variable (SILVA et al., 2010). The decline of this variable with the heightening of soil water stress was similar to what was observed by Pereira Filho et al. (2011), when analyzing the effects on castor bean culture of different soil water stress intensities. For these researchers the maximum fruit weight $(218.6 \mathrm{~g})$ was obtained with an irrigation level corresponding to $98 \% \mathrm{CAE}(456.8 \mathrm{~mm})$.

Analyzing the effect of irrigation frequencies on the weight of 100 seeds (Figure 8) it was found that the model that best fits the data was linear. This behavior shows that 
the reduction of soil water availability, imposed by the F10 treatment, significantly reduced the W100S from $37 \mathrm{~g}$ to approximately 26 g. Araújo and Ferreira (1997) showed a P100S of $45.25 \mathrm{~g}$ for the peanut crop grown without water stress. This conclusion agrees with Viana et al. (2012) on stating that a reduction of the soil water availability impairs grain filling during the post-flowering stage. In turn, the values of one hundred seed weight shown in this study were lower than those found by Freitas et al. (2010) working with the Guarani (37.70 g) and Paraguaçu (58.69 g) castor bean cultivars, under different soil water stress intensities.

Figure 8 - 100 seeds weight in peanut plants under different irrigation frequency

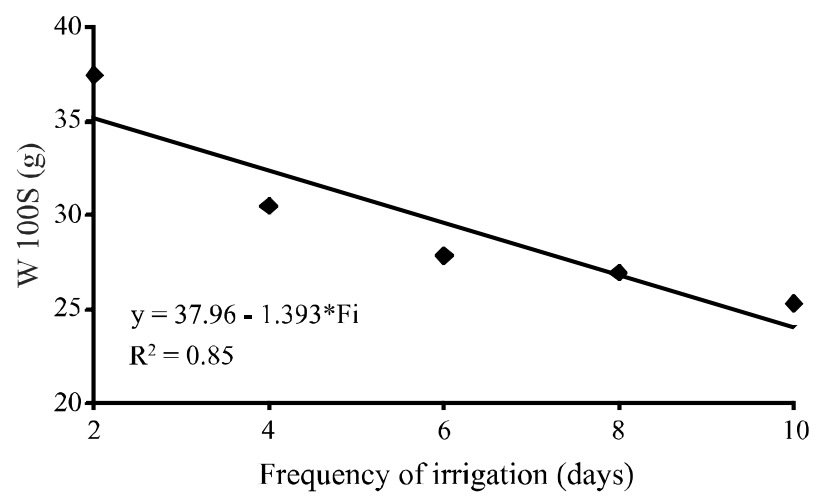

Analyzing the effect of the different frequencies of irrigation on productivity, through regression analysis, found that the linear model (Figure 9) showed a highly significant effect. There was maximum yield $\left(1.120 \mathrm{~kg} \mathrm{ha}^{-1}\right)$ with the frequency of irrigation of every two days $(\mathrm{F} 2)$, decreasing with increasing water stress induced by other treatments, reflecting directly in low yielding performance of the peanut crop. Possibly the studied cultivar does not have a genetic trait adapted to edaphoclimatic conditions of the study area, however, it produced only $2.7 \%$ less than the average of Ceará. The yield obtained with the irrigation frequency is below the average productivity, $1.151,6 \mathrm{~kg} \mathrm{ha}^{-1}$, in Ceará (IPECE, 2010).

In the case of water deficiency in soil, the plants present physiological disorders that can irreversibly compromise the agricultural production (MAROUELLI; SILVA, 2007; TAIZ; ZEIGER, 2009), or maximize its reserves and future highest yields, which according to Sepaskhah and Ahmadi (2010) would be a viable alternative for regions with limited water resources.

Working in field conditions, Rahmianna, Taugiq and Yusnawan (2009) found no significant effect on the yield
Figure 9 - Grain yield in peanut plants under different irrigation frequency

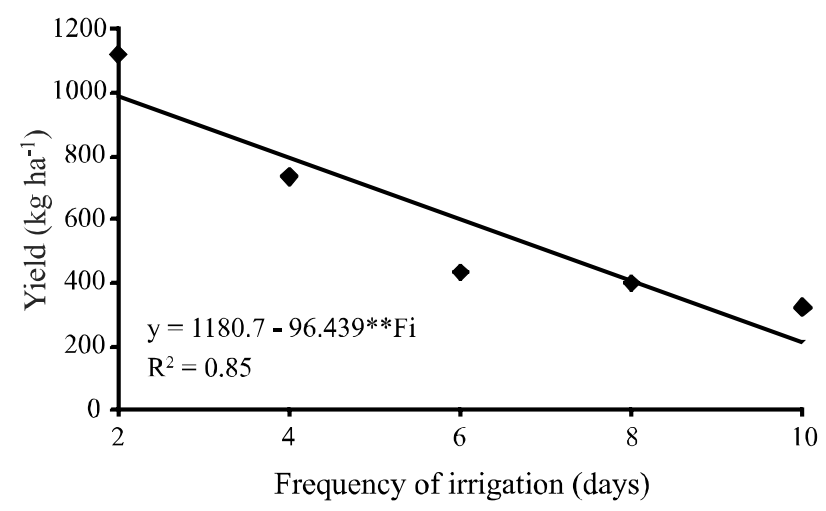

of the peanut crop under different irrigation frequencies. In greenhouse conditions, Pires et al. (2009), studying different frequencies of irrigation in tomato crop revealed that this crop had the highest yield in irrigation frequencies of one, three, four and five times a day. Contrary to this study, Braz et al. (2009), working in field conditions, with the lime crop, under different irrigation frequencies, observed no significant effect on this variable.

\section{CONCLUSIONS}

1. The highest irrigation frequency tested (every two days) promoted the best results for plant growth (leaf number, plant height, shoot dry matter) e for leaf gas exchange;

2. The highest yield of field grown peanuts at the conditions prevailing in Fortaleza, Ceará, is associated with the adoption of an irrigation frequency of two days.

\section{REFERENCES}

ALLEN, R. G. et al. Evapotranspiration del cultivo: guias para la determinación de los requerimientos de agua de los cultivos. Roma: FAO, 2006, 298 p. (Estudio Riego e Drenaje Paper, 56).

ANDRADE, J. A.; ABREU, F. G. Influência da temperatura e do teor de umidade do solo na área foliar e acumulação de matéria seca durante o estabelecimento da ervilha, do milho e do girassol. Revista de Ciências Agrárias, v. 30, p. 27-37, 2007.

ARAÚJO, W. F.; FERREIRA, L. G. R. Efeito do déficit hídrico durante diferentes estádios do amendoim. Pesquisa Agropecuária Brasileira, v. 32, n. 5, p. 481-484, 1997.

ASSUNÇÃO, H. F.; ESCOBEDO, J. F. Estimativa da exigência hídrica do amendoim usando um modelo agrometereológico. Revista Irriga, v. 14, n. 3, p. 325-335, 2009. 
BERNARDO, S.; SOARES, A. A.; MANTOVANI, E. C. Manual de irrigação. 8. ed. Viçosa: UFV, 2009. 625 p.

BRAZ, V. B. et al. Níveis e frequências de irrigação na limeira 'Tahiti' no estado do Piauí. Revista Ceres, v. 56, n. 5, p. 611619, 2009.

CECHIN, I. et al. Differential responses between mature and young leaves of sunflower plants to oxidative stress caused by water deficit. Revista Ciência Rural, v. 40, n. 6, p. 12901294,2010

CORREIA, K. G.; NOGUEIRA, R. J. M. C. Avaliação do crescimento do amendoim (Arachis hypogaea L.) submetido a déficit hídrico. Revista de Biologia e Ciência da Terra, v. 4, n. 2, p. 1-7, 2004.

EMPRESA BRASILEIRA DE PESQUISA AGROPECUÁRIA. Sistema brasileiro de classificação de solos. 2. ed. Rio de Janeiro: Embrapa Solos, 2006. 306 p.

FERNANDES, V. L. B. Recomendações de adubação e calagem para o estado do Ceará. Fortaleza: UFC, 1993. $248 \mathrm{p}$.

FLEXAS, J. et al. Decreased Rubisco activity during water stress is not induced by decreased relative water content but related to conditions of low stomatal conductance and chloroplast $\mathrm{CO}_{2}$ concentration. New Phytologist, v. 172, n. 1, p. 73-82, 2006.

FREITAS, C. A. S. et al. Produção de matéria seca e trocas gasosas em cultivares de mamoneira sob níveis de irrigação. Revista Brasileira de Engenharia Agrícola e Ambiental, v. 15, n. 11, p. 1168-1174, 2011.

FREITAS, C. A. S. et al. Comportamento de cultivares de mamona em níveis de irrigação por gotejamento em Pentecoste, CE. Revista Brasileira de Engenharia Agrícola e Ambiental, v. 14, n. 10, p.1059-1066, 2010.

INMAN-BAMBER, N. G. et al. Increasing sucrose accumulation in sugarcane by manipulating leaf extension and photosynthesis with irrigation. Australian Journal of Agricultural Research, v. 59, n. 1, p. 13-26, 2008.

INSTITUTO DE PESQUISA E ESTRATÉGIA ECONÔMICA DO CEARÁ. Anuário Estatístico do Ceará. Atividades econômicas, 2011. Disponível em: http://www2.ipece.ce.gov. br/publicacoes/anuario/anuario2010/atividadesEconomicas/ agropecuaria.htm. Acesso em: 18 out. 2011.

LARCHER, W. Ecofisiologia vegetal. 2 ed. São Carlos: Rima Artes e Textos, 2006. 550 p.

MACHADO, R. S. et al. Respostas biométricas e fisiológicas ao déficit hídrico em cana-de-açúcar em diferentes fases fenológicas. Pesquisa Agropecuária Brasileira, v. 44, n. 12, p. 1575-1582, 2009.

MAROUELLI, W. A.; SILVA, W. L. C. Water tension thresholds for processing tomatoes under drip irrigation in Central Brazil. Irrigation Science, v. 25, p. 411-418, 2007.

NOGUEIRA, R. J. M. C.; SANTOS, R. C. Alterações fisiológicas no amendoim submetido ao estresse hídrico.
Revista Brasileira de Engenharia Agrícola e Ambiental, v. 4 , n. 1 , p. $41-45,2000$.

NOGUEIRA, R. J. M. C. et al. Comportamento estomático e potencial da água da folha em amendoim cv. BRS 151L7 submetido a estresse hídrico. Revista Brasileira de Oleaginosas e Fibrosas, v. 10, n. 1, p. 985-991, 2006.

PEIXOTO, C. P. et al. Características agronômicas e produtividade de amendoim em diferentes espaçamentos e épocas de semeadura no recôncavo baiano. Bragantia, v. 67 , n. 3 , p. $563-568,2008$

PEREIRA FILHO, J. V. et al. Desempenho produtivo da mamoneira sob diferentes lâminas de irrigação e doses de potássio, no vale do Curú, CE. Revista Agropecuária Técnica, v. 32, n. 1, p 115-124, 2011.

PIRES, R. C. M. et al. Desenvolvimento e produtividade do tomateiro sob diferentes frequências de irrigação em estufa. Horticultura Brasileira, v. 27, n. 2, p. 228-234, 2009.

RAHMIANNA, A. A.; TAUFIQ, A.; YUSNAWAN, E. Pod yield and kernel quality of peanut grown under two different irrigations and two harvest times. Indonesian Journal of Agriculture, v. 2, n. 2, p. 103-109, 2009.

ROWLAND, D. L. et al. Primed acclimation of cultivated peanut (Arachis hypogaea L.) through the use of deficit irrigation timed to crop developmental periods. Agricultural Water Management, v. 113, p. 85-95, 2012.

SEPASKHAH, A. R.; AHMADI, S. H. A review on partial root-zone drying irrigation. International Journal of Plant Production, v. 4, n. 4, p. 1735-8043, 2010.

SHIMAZAKI, K. I. et al. Light regulation of stomatal movement. Annual Review of Plant Biology, v. 58, n. 1, p. $219-247,2007$.

SILVA, L. C.; BELTRÃO, N. E. M. Incremento de fitomassa e produtividade do amendoinzeiro em função de lâmina e intervalos de irrigação. Revista Brasileira de Oleaginosas e Fibrosas, v. 4, n. 2, p. 11-121, 2000.

SILVA, V. G. F. et al. Productive characteristics and water use efficiency in cotton plants under different irrigation strategies. Revista Brasileira de Engenharia Agrícola e Ambiental, v. 14, n. 5, p. 451-457, 2010.

SOUSA, M. A.; LIMA, M. D. B. Influência da supressão da irrigação em estádios de desenvolvimento do feijoeiro cv. Carioca comum. Revista Bioscience Journal, v. 26, n. 4, p. $550-557,2010$

TAIZ, L.; ZEIGER, E. Fisiologia vegetal. 4. ed. Porto Alegre: Artmed, 2009. $729 \mathrm{p}$

TASSO JÚNIOR, L. C.; MARQUES, M. O.; NOGUEIRA, G. A. L. A cultura do amendoim. Jaboticabal: UNESP, 2004. 218 p.

VIANA, T. V. A. et al. Lâminas de irrigação e coberturas do solo na cultura do girassol, sob condições semiáridas. Revista Irriga, v. 17, n. 2, p. 126-136, 2012. 